\title{
Prevalence of Stress Urinary Incontinence in Women from a Rural Community in the Brazilian Amazon
}

\author{
Do Rego $\mathrm{AD}^{1 *}$, Morais $\mathrm{ACM}^{2}$, Molisani $\mathrm{JT}^{2}$, \\ Nascimento LGA ${ }^{2}$ \\ ${ }^{1}$ Gynecology-Obstetrics, Federal University of Amapá, \\ Brazil \\ ${ }^{2}$ Medicine Student of Federal University of Amapá, Brazil \\ *Corresponding author: Aljerry Dias do Rêgo, \\ Gynecologist-Obstetrician, Specialist in Urogynecology \\ and Professor of the Federal University of Amapá, \\ Macapá, Amapá, Brazil
}

Received: March 17, 2021; Accepted: May 07, 2021; Published: May 14, 2021

\begin{abstract}
Introduction: Stress urinary incontinence affects a significant number of women and causes great loss of Quality of Life (QoL). Its prevalence varies from 15 to $41.5 \%$.
\end{abstract}

Objective: To assess the prevalence of Stress Urinary Incontinence (SUI) in women living in a rural community in Amapá, the main risk factors and quality of life assessment using a standardized questionnaire.

Methodology: A screening questionnaire was applied to 235 women residing in Igarapé da Fortaleza, in the city of Macapá, in 2015. Patients with SUI complaints were submitted to the King's Health Questionnaire (KHQ) questionnaire. For statistical processing, BioEstat software version 5.3 was used.

Results: The prevalence of SUI was $28.9 \%$ (68 women). A significant age difference was found between women with SUI (44.2) and without SUI (37.9 \pm 12.5 years). Childbirth, birth interval, smoking and Body Mass Index (BMI) showed to be statistically significant differences between groups. Variables such as number of deliveries, birth weight, menopause, education and race did not express a real difference.

Conclusion: The prevalence of SUI was $28.9 \%$. There was a significant difference in the group with SUI in terms of age, smoking, parity, interval between births and BMI. In assessing QoL in patients with SUI using KHQ, we found the worst results in general health perception, impact of incontinence, personal relationships, sleep/mood and severity of symptoms.

Keywords: Urinary incontinence; Epidemiology; Amazon region; Rura area; Amazon

\section{Introduction}

Urinary Incontinence (UI) is defined as the complaint of involuntary loss of urine [1]. UI can be divided into Stress Urinary Incontinence (SUI), which is defined as a complaint of urine loss due to some physical effort such as jumping, running and coughing. Urgency Urinary Incontinence (UUI) when there is a complaint of involuntary urine loss associated with urgency and Mixed Urinary Incontinence (MUI) when the involuntary loss of urine is associated with urgency and also with efforts $[2,3]$.

There are few Brazilian epidemiological studies. A study in Campinas (São Paulo) and (Mato Grosso) showed a prevalence of $35 \%$ and $21.4 \%$ of women with SUI $[4,5]$. In Italy, $15.3 \%$ of the women interviewed reported urinary loss, while in China it was 23\%; quite different from $41.5 \%$ in women from Saudi Arabia [6-8].

Several factors can contribute to the increase in the prevalence of UI, such as age, pregnancy, childbirth, vaginal delivery, menopause and obesity [9-11].

In Italian women with UI, $12.6 \%$ were nulliparous and $38.3 \%$ were secondary women. A study in Mexican women showed that UI was present in $58.1 \%$ in the group that had only normal delivery and $25.8 \%$ in the caesarean delivery group [12].
UI has a negative impact on women's Quality of Life (QoL), where social isolation, sexual disorders, family and work problems, anxiety, shame and depression are common. We can use standardized questionnaires to measure QoL. The King's Health Questionnaire (KHQ) has already been validated for Portuguese. It consists of 21 questions, divided into 8 (eight) domains: general health perception, impact of urinary incontinence, limitation of daily activities, physical and social limitations, social relationship, emotions and sleep/mood and two independent scales: one evaluates the severity of incontinence (measures of severity) and the other the presence and intensity of urinary symptoms. These scales are graded in 4 or 5 response options (Likert scale) $[13,14]$.

KHQ is scored for each of its domains. Values range from 0 to 100 and the higher the score, the worse the quality of life for that domain [13-15].

There is a scarcity of epidemiological studies related to UI in the Amazon Region, so the objective of this study was to describe the prevalence of S.U.I in women living in a rural community in the city of Macapá - AP.

\section{Methodology}

A cross-sectional study carried out to evaluate the prevalence 


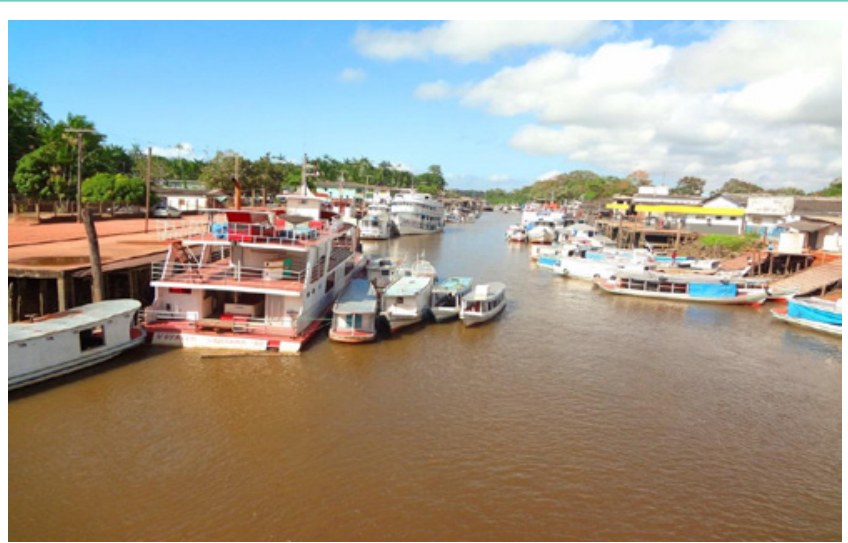

Figure 1: Igarapé da Fortaleza region.

of SUI and risk factors in women living in the Igarapé da Fortaleza community, 12 kilometers away by land from the city of Macapá/ AP. This community is divided by a small river (called the igarapé da Fortaleza), a direct tributary of the Amazon River (Figure 1). The female population at the time of the survey was 1,613 [16]. Most had low income and educational backgrounds, with a livelihood based on fishing and family farming. The houses are made of wood and the connection between them is made only by bridge $[17,18]$.

The study was approved by the ethics and research committee of the Federal University of Amapá (opinion no FR-347446/2011). Data were collected from August to December 2015.

235 women who attended the community primary healthcare center for the collection of pap smear participated in the research after informed consent.

Inclusion criteria were female sex, fixed residence in the Igarapé da Fortaleza community and age $\geq 20$ years. Pregnant women, under 20 years old, those with anatomical or physical restrictions and/or patients with urinary fistulas were excluded from the study.

Patients were evaluated using a screening questionnaire for clinical investigation of SUI complaints and risk factors. To women complaining of SUI, was applied the (KHQ) [13].

For data analysis, descriptive and inferential statistical methods were applied, using the Shapiro-Wilk test, Kruskal-Wallis, Chisquare and $\mathrm{G}$ test. The alpha significance level $=0.05$ was previously fixed for rejection of the null hypothesis. All statistical processing was performed using the BioEstat software version 5.3.

\section{Results}

Of the 235 women interviewed, 68 reported the presence of stress urinary incontinence. Thus, we divided into 2 groups: G I - stress Incontinence urinary group ( $\mathrm{n}=68)$ and G II - control group, that is, without SUI ( $\mathrm{n}=167)$.

The prevalence of SUI was $28.9 \%(n=68)$ of the assessed population (Figure 2).

Regarding the assessment of risk factors for SUI, there was a significant difference in terms of age ( $\mathrm{G}=44.2$ and $\mathrm{G} I \mathrm{I}=37.9$ years), smoking (G I 89.7\% and G II 10.2\% smokers), childbirth (G I = 4.7 and $\mathrm{G} \mathrm{II}=4.1$ deliveries), interval between deliveries $(\mathrm{G} I=2$ years

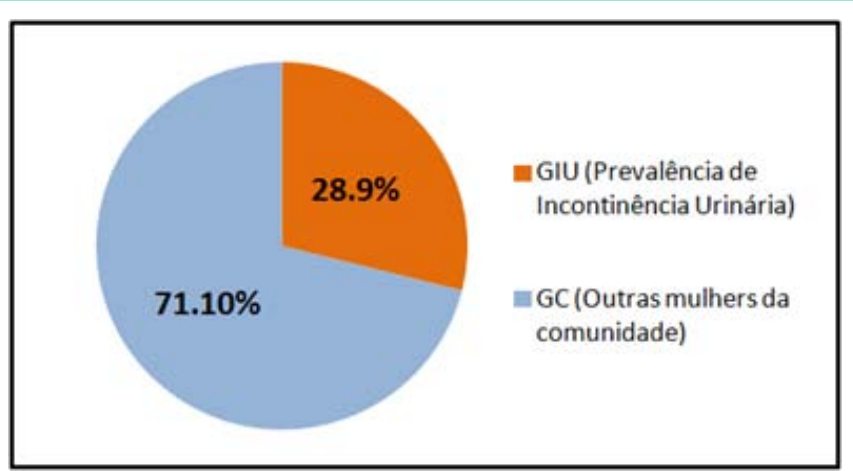

Figure 2: Prevalence of stress urinary incontinence in women living in a rural community in the city of Macapá in the State of Amapá, year 2015.

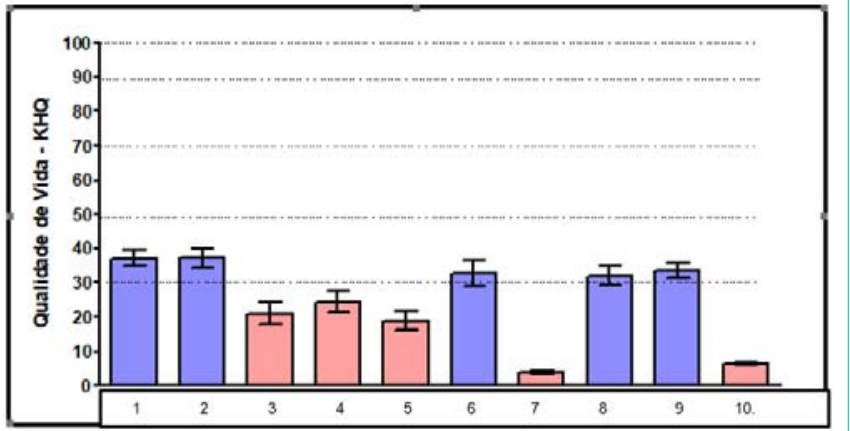

Figure 3: Average and standard error of quality of life (KHQ) of women, with SUI ( $n=68$ ), living in a rural community in the city of Macapá in the State of Amapá, year 2015. 1) General health perception; 2) Impact of incontinence; 3) Limitation of daily activities; 4) Physical limitation; 5) Social limitation; 6) Personal relationships; 7) Emotions; 8) Sleep/mood; 9) Severity measures; 10) Intensity symptoms.

Table 1: Age distribution (years) of women with SUI and without SUI, living in a rural community in the city of Macapá in the State of Amapá, year 2015.

\begin{tabular}{|c|c|c|c|}
\hline Age (years) & GI & GII & P* \\
\hline N & 68 & 167 & \multirow{2}{*}{0.0002} \\
\hline Arithmetic average & 44.2 & 37.9 & \\
\hline
\end{tabular}

*Student's t test.

and G II $=2.4$ years $)$ and body mass index $(\mathrm{BMI})(\mathrm{G} \mathrm{I}=26.9$ and $\mathrm{G} \mathrm{II}$ $=24.8)($ Table 1-3).

There was no significant difference in the following evaluated items: Education, marital status, presence of systemic arterial hypertension and Diabetes Mellitus, Normal deliveries (mean), Caesarean delivery (mean), home birth (mean), birth weight (NB), presence of women at menopause (Table 2 and 3 ).

The quality of life assessment of women with SUI complaints showed that there was a statistically significant difference ( $\mathrm{p}$-value $<0.0001^{*}$ ) between the quality of life domains.

The worst domains (most affected general health perception, impact of incontinence, personal relationships, sleep/mood (Table 4 and Figure 3).

\section{Discussion}

In the literature, we found a large variation in the prevalence 
Table 2: Distribution of general characteristics in women, SUI and without SUI, living in a rural community in the city of Macapá in the State of Amapá, year 2015.

\begin{tabular}{|c|c|c|c|c|c|}
\hline & \multicolumn{2}{|c|}{ GI } & \multicolumn{2}{|c|}{ GII } & \multirow{2}{*}{$\mathbf{P}$} \\
\hline & $\mathbf{N}$ & $\%$ & $\mathbf{N}$ & $\%$ & \\
\hline Education & & & & & 0.471 \\
\hline Illiterate & 5 & 7,4 & 19 & 11,4 & \\
\hline Elementary & 37 & 54,4 & 91 & 54,5 & \\
\hline College & 25 & 36,8 & 50 & 29,9 & \\
\hline Higher Education & 1 & 1,5 & 7 & 4,2 & \\
\hline Race & & & & & 0.14 \\
\hline White & 21 & 30,9 & 70 & 41,9 & \\
\hline Black & 11 & 16,2 & 15 & 9,0 & \\
\hline Mixed race & 36 & 52,9 & 82 & 49,1 & \\
\hline Marital Status & & & & & 0.098 \\
\hline Married & 59 & 86,8 & 129 & 77,2 & \\
\hline Divorced & 2 & 2,9 & 2 & 1,2 & \\
\hline Single & 3 & 4,4 & 26 & 15,6 & \\
\hline Widowed & 4 & 5,9 & 10 & 6,0 & \\
\hline Smokers & & & & & $<0.0001^{*}$ \\
\hline Yes & 61 & 89,7 & 17 & 10,3 & \\
\hline No & 7 & 10,2 & 150 & 89,8 & \\
\hline Pathology & & & & & 0.1891 \\
\hline Diabetes & 1 & 1,5 & 1 & 0,60 & \\
\hline Hipertensive disease & 14 & 20,6 & 18 & 10,78 & \\
\hline
\end{tabular}

Hypothesis testing: $\mathrm{G}$ test for independent samples.

of UI, ranging from 8.5 to $68.8 \%$, this difference possibly being explained by the little uniformity in the terminology, definitions used, questionnaires applied and socio-cultural variability between countries and the age group surveyed [19]. The prevalence of SUI found in women from Igarapé da Fortaleza was $28.9 \%$, similar to that found in Greece (27\%) [20] and in the city of Campinas (SP) with $35 \%[4]$.

Estimates based on the American population suggest that approximately 20 million women experience urinary incontinence during their lives and more than $77 \%$ of elderly women living in nursing homes have the pathology [21].
The age analysis showed a significant difference between the groups, in the SUI group the average age was 6.3 years higher. A study carried out in São Paulo with 1,200 women, the prevalence of SUI was $20.4 \%$ and the average age was 51.9 years [22].

Regarding childbirth, there was a significant difference between the groups, with a higher average delivery in the SUI group (mean: $4.7 \times 4.1)$ and a shorter interval between deliveries ( $2 \times 2.4$ years). In Italian women with UI, $12.6 \%$ were nulliparous and $38.3 \%$ were on their second birth. A study in Brazilian women showed that the average pregnancy in the group with SUI was 3.19 and in the group without SUI $2.62(\mathrm{p}=0.013)$ [5].

The association between BMI and UI was evident in our study, since the G I group's average BMI was higher ( 26.9 x 24.8). Analysis performed in 2018 with 221 obese patients eligible for bariatric surgery, found a prevalence of $53.4 \%$ of UI 23 . In obese women, $60 \%$ reported SUI and, one year after bariatric surgery, the prevalence of SUI dropped to $37 \%$ [24].

The present research showed the association of smoking with SUI in women from Igarapé da Fortaleza, a fact compatible with other studies, such as a bibliographic review that highlighted smoking as one of the main risk factors for UI. The risk is increased because the smoker frequently has a chronic cough and leads to a significant increase in bladder pressure, causing a direct or indirect effect on the bladder or urethra, which can damage the components and the sphincter mechanism [25].

In the assessment of quality of life in patients with SUI using $\mathrm{KHQ}$, we found the worst results in the following items: general health perception, impact of incontinence, personal relationships, sleep/mood and severity symptoms.

Research carried out on 40 women treated at the University Hospital Ana Bezerra (UFRN) using the KHQ identified a negative impact mainly in the domains of daily activities, physical limitations, health perception and in the domain related to Emotions. Among SUI carriers, depression was present in $45.0 \%$ and anxiety in 50.0\% [26].

Another similar study, using KHQ with 40 institutionalized elderly women from the cities of Petrolina and Juazeiro, UI was reported by $47.50 \%$. The domain of KHQ that suffered the most interference in quality of life was that of health perception with $51.31 \%$; in other

Table 3: Distribution of numerical variables that characterize women, with and without SUI, living in a rural community in the city of Macapá in the State of Amapá, year 2015 .

\begin{tabular}{|c|c|c|c|c|c|c|c|}
\hline & \multicolumn{3}{|c|}{ GI } & \multicolumn{3}{|c|}{ GII } & \multirow{2}{*}{$\mathbf{P}$} \\
\hline & Median & Mean & Standard Deviation & Median & Mean & Standard Deviation & \\
\hline Parity & 4.8 & 4.7 & 2.7 & 4 & 4.1 & 3 & $0.0307^{*}$ \\
\hline Normal Birth & 4 & 4.4 & 2.6 & 4 & 4.2 & 2.8 & 0.3703 \\
\hline Cesarian Birth & 1 & 1.6 & 0.9 & 1 & 1.4 & 0.7 & 0.5257 \\
\hline Home Birth & 3 & 3.7 & 2.5 & 3 & 3.4 & 2.9 & 0.3434 \\
\hline Birth Interval & 2 & 2 & 1.2 & 2.4 & 2.5 & 2 & $0.0036^{*}$ \\
\hline Weight NB & 3600 & 3577 & 492 & 3500 & 3430 & 687 & 0.1747 \\
\hline BMI & 26 & 26.9 & 4.7 & 24 & 24.8 & 4.1 & $0.0009^{* *}$ \\
\hline Menopause & 48 & 47.2 & 2.7 & 49 & 48.1 & 2.7 & 0.1828 \\
\hline
\end{tabular}

"Teste U de Mann-Whitney.

${ }^{*}$ Teste t de Student. 
Table 4: Quality of life assessment of women with SUI ( $n=68)$, accessed by Kings Health Questionnaire (KHQ), living in a semi-rural community in the city of Macapá in the State of Amapá, year 2015

\begin{tabular}{|l|c|c|c|c|c|}
\hline & Min & Max & Median & Mean & Standard Deviation \\
\hline Overall perception of helth & 25 & 75 & 25 & 37.1 & 19.6 \\
\hline Impact of incontinence & 0 & 100 & 33.3 & 37.2 & 23.2 \\
\hline Limitations on daily activities & 0 & 100 & 8.3 & 21.1 & 26 \\
\hline Limitation on physical activities & 0 & 100 & 16.6 & 24.5 & 2.8 \\
\hline Social limitations & 0 & 88.8 & 16.7 & 18.9 & 3.2 \\
\hline Personal relationships & 0 & 100 & 33.3 & 32.7 & 22.9 \\
\hline Emotions & 0 & 8.8 & 3.3 & 3.9 & 28.9 \\
\hline Sleep, wellness & 0 & 83.3 & 33.3 & 32.1 & 2.8 \\
\hline Severity measurements & 0 & 73.3 & 33.3 & 33.6 & 2.7 \\
\hline Symptom intensity & 3 & 14 & 6 & 6.6 & 2.3 \\
\hline
\end{tabular}

P-value $<0.0001^{*}$, Kruskal-Wallis test.

domains, the impact of UI was considered low, however on the scale of symptoms the elderly women reported that UI affects "more or less" or "a lot" their lives [27].

\section{Conclusion}

The prevalence of SUI in women living in a rural community in the Brazilian Amazon was $28.9 \%$ and the risk factors associated with SUI were Age, smoking, childbirth, interval between births and body mass index. Quality of life was significantly affected, especially in the domains of health perception, UI impact, personal relationships and sleep and mood.

\section{References}

1. Haylen BT, et al. An International Urogynecological Association (IUGA)/ International Continence Society (ICS) Joint Report on the Terminology for Female Pelvic Floor Dysfunction. Neurourol Urodyn. 2010; 29: 4-20.

2. Abrams $P$, Cardozo L, Fall M. A padronização da terminologia na função do trato urinário inferior: relatório do subcomitê de padronização da International Continence Society. Urology. 2003; 61: 37-49.

3. Henkes D, Fiori A. Incontinência Urinária: o impacto na vida de mulheres acometidas e o significado do tratamento fisioterapêutico. Semina: Ciências Biológicas e da Saúde. 2015; 36.

4. Guarisi T, Pinto-Neto AM, Osis MJ, Pedro AO, Paiva LHS, Faundes A Procura de serviço médico por mulheres com incontinência urinária. RBGO. 2001; 7: 439-443.

5. Gomes GV, Silva GD. Incontinência urinária de esforços em mulheres pertencentes ao programa saúde da família de Dourados (MS). Rev. Assoc. Med. Bras. 2010; 56: 649-654.

6. Álvaro R, Araco F, Gravante G, et al. Aspectos epidemiológicos da incontinência urinária em uma população feminina de uma região italiana. In Urogynecol J. 2010; 21: 873-883.

7. Liu B, Huang SS, Wu Q, Wu DL. Prevalence and risk factors of urinary incontinence among Chinese women in Shanghai. Int J Clin Exp Med. 2014 7: 686-696.

8. Badr A, Brasha H, Raddadi RA, Noowali F, Ross S. Prevalence of urinary incontinence among Saudi women. International Journal of Gynecology and Obstetrics. 2012; 117: 160-163.

9. Taylor DW, Weir M, Cahill JJ, Risk DE. The self-reported prevalence and knowledge of urinary incontinence and barriers to health car seeking in a community sample of Canadian women. American Journal of Medicine and Medical Sciences. 2013; 3: 97-102.

10. Osborn DJ, Strain M, Gomelsky A, Rothschild J, Dmochowski R. Obesity and female stress urinary incontinence. Urology. 2013; 82: 759-763.

11. Hunskaar S, Arnold EP, Burgio K, Diokno AC, Herzog AR, Mallett VT. Epidemiology and natural history of urinary incontinence. Int Urogynecol J. 2000; 11: 301-319.

12. Garcia H, Denman C, Harlow S. Measuring urinary incontinence in a population of women in northern Mexico: Prevalence and severity. Int Urogynecol J. 2012; 23: 847-854.

13. Tamanini José Tadeu Nunes, D'Ancona Carlos Arturo Levi, Botega Neury José, Rodrigues Netto Jr Nelson. Validação do "King's Health Questionnaire" para o português em mulheres com incontinência urinária. Rev. Saúde Pública. 2003; 37: 203-211.

14. Kelleher CJ, Cardozo LD, Khullar V, Salvatore S. A new questionnaire to assess the quality of life of urinary incontinent woman. British Journal of Obstetrics and gynecology. 1997; 104: 1374-1379.

15. Charalambous S, Trantafylidis A. Impact of urinary incontinence on quality of life. Pelviperineology. 2009; 28: 51-53.

16. Instituto Brasileiro de Geografia e Estatística (IBGE). Recenseamento Geral da População, 2010. Amapá, 2012.

17. Diretrizes para uma política de desenvolvimento sustentável da região do Bailique. Governo do Estado do Amapá, Rurap. 1996.

18. CAACESS - Centro Amapaense de Atividades Culturais, Econômicas e Social. Bailique: Desenvolvimento sustentável no delta do amazonas. Governo do Estado do Amapá, secretaria estadual da educação - divisão de educação ambiental. Macapá/Amapá. 2000.

19. Vallejos Gabriel, Guzmán Rojas Rodrigo, Valdevenito Juan Pablo, Fasce Gerardo, Castro Daniela, Naser Michel, et al. Incontinencia Urinaria en el Adulto Mayor. Rev. chil. obstet. ginecol. 2019; 84: 158-165.

20. Liapis A, Bakas P, Liapi S, Sioutis D, Creatas G. Epidemiology of female urinary incontinence in the Greek population: EURIG study. In Urogynecol J. 2010; 21: 217-222.

21. Irwin Gretchen M. Urinary Incontinence. Family Medicine Residency Department of Family and Community Medicine, Wesley Medical Center, University of Kansas School of Medicine-Wichita, 1010 North Kansas, Wichita, KS 67214, USA. 2019.

22. Dellú Máyra Cecilia, Schmitt Ana Carolina Basso, Cardoso Maria Regina Alves, Pereira Wendry Maria Paixão, Pereira Elaine Cristina Alves, Vasconcelos Érika da Silva Flauzino, et al. Prevalence and factors associated with urinary incontinence in climacteric. Rev. Assoc. Med. Bras. 2016; 62: 441-446.

23. Nygaard Christiana Campani, Schreiner Lucas, Morsch Thiago Picolli, Saad Rodrigo Petersen, Figueiredo Marina Faria, Padoin Alexandre Vontobel. Urinary Incontinence and Quality of Life in Female Patients with Obesity. Rev. Bras. Ginecol. Obstet. 2018; 40: 534-539. 
24. Prabhu SA, Shanbhag S. Prevalence and risk factors of urinary incontinence in women residing a tribal area in Mahsrashtra, India. Journal of research in health Sciences. 2013; 13: 125-130.

25. Higa Rosângela, Lopes Maria Helena Baena de Moraes, Reis Maria José dos. Fatores de risco para incontinência urinária na mulher. Rev. esc. enferm. USP. 2008; 42: 187-192.

26. Alencar-Cruz Jeferson Messias de, lira-lisboa Lilian. O impacto da incontinência urinária sobre a qualidade de vida e sua relação com a sintomatologia depressiva e ansiedade em mulheres. Rev. salud pública. 2019; 21: e150016

27. Pitangui Ana Carolina Rodarti, Silva Rosemary Gonçalves da, Araújo Rodrigo Cappato de. Prevalência e impacto da incontinência urinária na qualidade de vida de idosas institucionalizadas. Rev. bras. geriatr. gerontol. 2012; 15 619-626. 